\title{
The Case of the Eleven-linch Fish: A Study in Administrative Discretion
}

Don Jaccard

\begin{abstract}
The complex, yet vague nature, of legislation being generated by lawmakers in Washington, DC requires that public administrators be afforded administrative discretion in carrying out their respective duties. It is no longer possible for policymakers to be fully informed regarding the multitude of variables that exist in the offshore fishing environment, nor is it possible to articulate that spectrum of variables in codified laws and regulations. The academic debate between controlling the exercise of administrative discretion on the one hand and extending the leash of judgment on the other has been around as long as the profession of public administration. In the case of the eleven-inch fish (the fish is one inch shy of being a legal catch), the public administrator on the scene of the infraction has a choice to make. The administrator can choose to overlook the incident, issue a warning, or issue a $\$ 100$ notice of violation and seize the fish. I know which alternative I chose. The question is, which alternative would you choosen?
\end{abstract}

It was a beautiful day. The late afternoon sun was shimmering across the surface of the ocean. My crew and I were into our third day of a scheduled four-day patrol, meandering along the south Texas coastline enforcing federal fisheries laws. My two-man boarding team was currently aboard the pleasure craft "U-Catch-Em," conducting an inspection to ensure that Mr. Foley, the owner/ operator of the boat, and his two young sons were in compliance with all applicable federal laws and regulations.

Mr. Foley gladly showed the boarding officer the fish he and his boys had caught that morning. They had been fairly successful and were quite proud of their catch: ten red snappers, now properly iced down in the cooler. Dinner was looking good. There was one small problem, however. By law, a fish like the red snapper must measure twelve inches, nose to tail, to be retained as a legal catch. One of the fish in Mr. Foley's cooler was only eleven inches long. What should the boarding officer do? We were fifty miles off- shore; not another boat was in sight. Nine of the ten fish were of legal size. Was Mr. Foley breaking the law? Is the too-small fish worthy of consideration? How serious is this infraction? Does it matter?

As the public administrator in this scenario, I had a choice to make. In the case of Mr. Foley, I saw three options. One, I could dismiss the incident and tell these folks to have a nice day. Two, I could seize the undersized fish and issue a written warning. Or three, I could seize the fish and issue $\mathrm{Mr}$. Foley a notice of violation, which carries with it a $\$ 100$ fine for violating federal law. It was within my discretion to choose one of these three courses of action. I know which choice I made. Which choice would you have made?

This simple illustration of administrative discretion is representative of judgements and decisions that public administrators make every day, whether they occur in the confines of an environmentally controlled office in Washington, DC or on the rolling deck of a Coast Guard patrol boat in the Gulf of Mexico. In these situations, the letter of the law may be clear, but the specific circumstances surrounding an apparent infraction require the judgment of the public administrator in order to accurately apply the spirit of the regulation in question. The question of whether or not, and to what extent, the public administrator is empowered to exercise such judgement is one that has been of debate since the founding of public administration as a profession.

Public administration has evolved through the twentiethcentury into an accepted profession, replacing local party politics as the primary source of jobholders in the public

Don Jaccard is a lieutenant commander in the United States Coast Guard and a second year candidate for a Master's of Public Administration at The George Washingron Universicy. He holds a Bachelor of Science in Law and Public Policy from the University of Maryland-University College. 
sector of the late-nineteenth century. The result has been the development of a civil service comprised of experts in administering the public policy and programs of elected representatives at the federal, state and local levels. As public administration has evolved, so, too, have the principles on which the field is based. Efficiency and economy have generally been regarded as the touchstones of public administration. On a basic level, efficiency and economy in this context mean achieving the greatest public good for the budget dollars available and accomplishing program goals for the fewest dollars possible. In contemporary times, the postmodern public servant has been called on to advance these two principles to a higher order; he or she is required to determine for whom public policies and programs are efficient and economic.

An understanding of how the notion of administrative discretion has evolved will help flesh out the dilemma presented to me by the eleven-inch fish. It was, of course, Woodrow Wilson who first suggested the politics/administration dichotomy, thus establishing the "classical" view of public administration. Wilson's dichoromy defined policymaking and policy implementation as two discrete functions. From this perspective, there is no need, nor is there desire, to commingle the functions of politics and administration. It is illuminating to consider that the classi$\mathrm{cal}$ approach was developed at a time when the functions of government would be considered simple in comparison to today's globalized, technologically driven environment. Frank Goodnow advanced Wilson's dichotomy by concluding that politics deals with the policies or expressions of the will of the state, while administration focuses on the execution of that will. ${ }^{2}$

Major social and political events of the 1930's and 1940's ushered public administration into an era of reform and transformation. Dwight Waldo observed that the New Deal and World War II efforts, for example, were major managerial endeavors that forever changed the shape and function of the administrative state. The politics/administration dichotomy lost its viability as it was no longer possible to consider these two functions as being discrete. In fact, through their innovative contributions to the public policies of the time, public administrators demonstrated that they had quantifiable contributions to make in the domain of policy development. In order to capitalize on those contributions, it became necessary for the policymaker and policy administrator to engage in the free exchange of ideas. In discussing the application of policy, the public administrator gains valuable insight into the implied objectives, or legislative intent, of the policymaking body and is thus bet- ter equipped to exercise discretion in administering its laws and regulations.

This dialogue between policymaker and administrator also serves to develop a trust between the two parties", a trust that serves the public interest by combining Herbert Simon's value judgement of politics with the factual judgement of administration. ${ }^{3}$ This foundation of trust then cultivates the policymaker's confidence in the administrative discretion exercised by the administrator in carrying out the responsibility of serving a democratized society that is centered on personal freedoms.

H. George Frederickson heralded the era of the New Public Administration. In this modern era, Frederickson added social equity as another arrow in the quiver of the administrator's arsenal of principles that already consisted of efficiency and economy. ${ }^{4}$ By adding social equity to this arsenal, Frederickson calls on the administrator to consider the distributive effects of a policy and to recognize that a policy may be efficient for one group while being inefficient for another. Similarly, a policy may be economical for one group while being costly for another.

The value of this expanded arsenal is readily apparent in today's cultural context, where the public administrator is left to assume responsibility for assessing life's situations and determining the bounds of our cultural norms. Legislation has grown increasingly vague and frequently relies on the broad mandate for public administrators to "act in the public interest." Thus, the responsibility for exercising the will of the state has been foisted onto the administrator, leaving the administrator and the concerned interest groups to "figure it out." For Theodore Lowi, this violates the public interest as it shifts power from the elected official to the career bureaucrat. ${ }^{5}$ For Lowi, this shift in power violates the separation of powers doctrine, and thus, the Constitution.

While Lowi's argument may be compelling, it has yet to be accepted by Congress. So, for the time being, the public administrator must continue to independently operationalize the concept of "public interest" and serve society responsibly. In accomplishing this task, the administrator is called on to maintain order between groups of citizens with opposing interests in the same policy area. Here, it is not necessary for the administrator to treat groups of citizens equally. Rather, it is the duty of the administrator to equitably assess the values and claims of groups impacted by a given policy. 
Balancing the competing values and claims of interested parties, then, becomes a determination of what is fair. As the public administrator in the fish case, I was compelled to consider several questions. Was it fair to the environmentalist or the health of the fisheries resource that Mr. Foley be allowed to violate the law and take a fish that had been determined to be one inch too short? On the other hand, was it fair to Mr. Foley that he be assessed a fine of $\$ 100$ for possessing one fish, out of ten, that was a mere one inch undersize? The point here is that the distributive effects of an alternative be taken into consideration and weighed before the administrator exercises discretion.

These issues lead to Carl J. Friedrich and Herman Finer, who engaged in the most substantive debate on administrative discretion, beginning in the 1940's, and whose views will further elucidate the dilemma presented by the eleven-inch fish. Friedrich and Finer would reach very different conclusions in the case of the "illegal" fish. Friedrich dismisses the politics/administration dichotomy and subscribes to the notion that public policy is a continuous process, evolving over time. The administrator is necessarily engaged in the policy or program throughout its life. Friedrich comes across as sympathetic to the challenges presented to the administrator who is oftentimes left to deal with novel and complex situations that require notable creative, almost entrepreneurial ability to solve problems. ${ }^{6}$ In being creative, the administrator takes on the significant role of policy interpreter for the public at large.

Friedrich recognizes that the average citizen experiences difficulty in interpreting policy implications from a societal perspective vis-à-vis a more local perspective that is easier to comprehend. Therefore, it has become the job of the public servant, for example, to explain why a fish has to be twelve inches long to be considered a legal catch. There may be economic implications for the fishing industry in Japan or there may be survival implications for one species of fish or another, yet it may be difficult for Mr. Foley to understand why I would choose to spend two hours of my afternoon on one eleven-inch fish. Here, Friedrich would have understood since he called on the administrator to educate the fisherman in order to fulfill the responsibility of interpreting policy for the public. ${ }^{7}$

Finer, in contrast, accepts the politics/administration dichotomy of the classical school. To Finer, the public servant is not in a position to decide on a course of action, and there is really no question on the matter. Instead, it is the responsibility of the legislature to determine the appropri- ate course of action for the public servant to the most specific degree feasible and the administrator is to be responsible to the elected official for enforcing the letter of the law. There is no place for the administrator's interpretation. While accepting Finer's appreciation for a wellwritten, comprehensive regulation, I do not accept his theory as being practical in every situation that I might encounter fifty miles offshore.

Finer's view of discretion, or lack thereof, may work in an idealistic environment where all factors in a situation are predictable. In my experience offshore, this is a rare occurrence. There are too many situations in life where it is simply too easy to violate laws and regulations without any wrongful intent, or any discernible impact on society. ${ }^{8}$ Furthermore, the nation's court system would be overwhelmed if each law enforcement official in the country, be it on land or at sea, were to document every legal infraction they observed. Here are two real-life scenarios worth pondering in order to shed further light on the need for administrative discretion.

A colleague of mine, operating in the Gulf of Alaska, experienced a situation that apparently had not been considered by lawmakers. While on patrol he found a commercial fishing vessel anchored in a sea lion rookery-clearly a violation of federal law. Upon closer inspection, however, my colleague found that the captain of the vessel had a clear reason for being anchored in the rookery: he and his crew had been underway for the past two days in a horrific storm. The boat had suffered extensive damage to its rigging and the crew was fatigued to the point of delirium. In this situation, the captain determined that in order to save his boat and his crew he must seek refuge behind the closest point of land - the sea lion rookery-and drop anchor. His actions were honorable, any mariner would agree, but in anchoring within the charted limits of the rookery he broke the law. Friedrich, favoring discretion, would say to show some compassion and overlook the infraction while Finer, preferring adherence to the letter of the law, would say to "write him up."

A similar dilemma arose in the Gulf of Mexico. A commercial fishing vessel made a radio call seeking emergency medical assistance. In the process of retrieving the boat's long-line fishing gear, a ten-inch fishhook had pierced a sailor's abdomen and we diverted our patrol boat to assist in effecting the evacuation of the injured sailor via helicopter hoist at sea. Afterwards, we proceeded to complete a boarding of the vessel and found a number of fishing violations, including the fact that the fishing crew, in attendeding 
to the needs of their injured shipmate, had failed to toss back into the water all the sea life that was not part of the target harvest, otherwise knownas bycatch. Failure to return the bycatch to the sea is a violation of federal law when the bycatch includes endangered species, but federal law is silent on whether delaying the return of the bycatch is a violation when the delay is attributable to time spent saving a shipmate's life. Under this particular set of circumstances, it was clear that there was no wrongful intent on the part of any member of this fishing crew. The crew had made the judgement to value human life more highly than that of an endangered fish. Had our roles been reversed, I am sure that I would have reached the same conclusion.

As a public administrator, how do I account for the circumstances surrounding legal infractions that seem to mitigate the severity of the "crime" committed? In carrying out my responsibility to administer federal regulations, it is likely that I will consider not only the text of the law but also the legislative intent behind the law. Additionally, there will be factors relevant to the local environment that will enter into my decisionmaking process. Likewise, as offered by Frederickson, I will seek to balance a certain level of social equity in the enforcement of relevant statutes offshore.

Allow me to introduce a few hypothetical scenarios in the case of Mr. Foley. What if Mr. Foley's fish ruler fell overboard and he was left to make an honest judgement as to the size of a fish by "eyeballing" it next to one he knew to be legal? So, he missed by one inch. Did he really violate the law? What if the eleven-inch fish is the first one his eight-year-old, autistic son ever caught? Should the law supercede this monumental event in the life of a child? Some would argue that this one small victory for the child is more important than the effect of the removal of the fish on the overall health of the fish resource. In these selective situations, it is imperative that the public servant be afforded the latitude to exercise judgement at the scene of the "violation" in determining whether or not to take administrative action.

Confronted with my hypothetical scenarios, Finer would argue that the administrator has a duty to act responsibly, but he does not suggest the administrator confuse this responsibility with any illusion of autonomy. The administrator is the agent of authority, and as such, is bound by a duty to act within the strictest limits of the law under that authority. For Finer, the question of the fish is not a question at all. It would be my duty to seize the fish and issue Mr. Foley a notice of violation. The concept of administrative discretion is moot in his view.
While accepting Finer's appreciation for accountability and consistent interpretation of the law, I find myself chafing at the shackles of his restrictive philosophy. The world is too complex for political representatives to draft legislation that effectively captures the spectrum of situations occurring on the streets, or waters, of the United States. Additionally, as a public servant in this modern era, I have come to expect a certain degree of empowerment in carrying out my assigned duties. By being engaged in enforcement activities relating to federal laws and regulations off the south Texas coast, I view myself as being uniquely qualified to make judgments regarding the severity of the eleven-inch fish "crime." It may be possible for me to have a greater impact on the red snapper fishery by allowing this one infraction to go undocumented than by enforcing the strict letter of the law. John Burke, while not the greatest advocate of administrative discretion, supports this notion. Burke writes, "In contrast to the somewhat limited opportunities for exercising discretion in responding to harms or extending rights as principles, bureaucrats can generally make strong claims for autonomy and discretion when matters of professional expertise arise."

In exercising discretion, it is always important for the public administrator to consider the public interest. The public interest is not definable, nor is it something one can go out and find. E. Pendleton Herring views the public interest as a symbol designed to introduce unity, order, and objectivity to the practice of pubic administration. He suggests that public interest is to the bureaucracy what the due process clause is to the judiciary. ${ }^{10}$ One method of arriving at the public interest is to engage in a public dialogue. In this sense, the public interest is not intended to reflect the needs or desires of the entire population. Rather, the public interest will be derived from the expressed view of the sector of the population impacted by a program or policy.

Rounding out this discussion on discretion, it is instructive to consider the work of Michael Harmon. Harmon accepts the notion that administrative discretion has become a necessity out of the erosion of the politics/administration dichotomy. I use the term "accept" here, because while Harmon does not reject the need for discretion, he does not fully embrace the notion either. Harmon recognizes that an overly strict rule of accountability forestalls any significant discretion and leads to the exercise of discretion only in the most extraordinary cases-those that require compelling justification. He suggests two competing requirements in exercising administrative discretion. First, the administrator must be held accountable to a hierarchy 
and political superiors. And second, administrators must be given the requisite authority to make discretionary decisions in carrying out their duties. It is a necessity of the profession to be placed in positions that call for the handling of unique problems or operating within contexts that could not have been considered or expressed in any written statute. ${ }^{11}$

In this respect, the administrator remains accountable to the hierarchical, elected body for the proper execution of the will of the state. If this expressed level of responsibility, as accountability, is coupled with the notion discussed earlier, of a trust built through dialogue, then the administrator is provided an arena with reasonable bounds within which he or she can exercise discretion in carrying out the will of the state.

Returning once again to the fish at hand, regardless of my ultimate decision, I have a responsibility to act. Mark Bovens sums up my situation in this manner, "A responsible person allows the possible consequences of his conduct to play a role in his decisions. In so doing, he must pay special attention to the consequences of his conduct for others... Responsible conduct implies seeking and weighing alternatives on the basis of a calculation of the consequences for the interests of all those involved." 12

While this article has focused on my strong desire for public administrators to be afforded latitude in exercising administrative discretion, this should not be viewed as support for indiscriminate license in randomly or inconsistently enforcing the laws and regulations enacted by the legislature. According to O.C. McSwite, what I am advocating is that administrators indeed act as Men of Reason.

McSwite defines a Man of Reason as the public administrator who "seeks to minimize the discretion he has to exercise because the more he can do this, the more correct and legitimate his actions will be." ${ }^{.13}$ McSwite goes on to describe an internal struggle for the administrator. I view this struggle as the person seeking to separate the role of private citizen (eleven-inch fish-no big deal) from the duty of the public servant (agent of the democratically elected official). In this light, the ultimate question for me boils down to whether or not I believe the suspect citizen (i.e. Mr. Foley) can be trusted to manage the fishery resource without my oversight. History says that he cannot. If you allow fishermen, for instance, to take fish unfettered from a common resource then they will do so until there are no more fish. This is human nature and is seen as unavoidable. ${ }^{14}$
So, how did I use my judgement in resolving the case of the eleven-inch fish and what were the consequences of that action? I chose option 3-seize the fish and issue Mr. Foley the $\$ 100$ notice of violation. A synopsis of the consequences of my decision boils down to three fiontsthe fisherman, the fishery, and the public servant. The consequences for Mr. Foley were minimal. He loses a fish and receives a notice of violation and a $\$ 100$ fine. $\mathrm{Mr}$. Foley is then permitted to continue fishing for as long as he wishes. Hopefully, the consequences for the red snapper fishery are increased awareness of the declining health of the resource and additional time for the fishery to replenish. And, finally for me, the consequence is that $\mathrm{Mr}$. Foley may not necessarily think I'm much of a good guy, but he cannot fault me for enforcing a federal law that is designed to protect the natural resources of his country.

There were a number of environmental factors that entered into this decision and I would like to expand on those now. Among the factors I took into account were the sea-state, visibility, direction and speed of the wind. Could these factors have pushed Mr. Foley off course and into a regulated area that he had intended to avoid? I also considered $\mathrm{Mr}$. Foley's level of expertise with boating, navigation, and fishing, the level of expertise of my boarding officer, the state of my crew and their ability to function as a professional and competent team, their knowledge of the statutes regarding this particular fish species, and whether another boat, in need of search and rescue assistance, would call me away from Mr. Foley. All of these variables are dynamic in nature and play a significant role in my ultimate decisionmaking process. A violation in the middle of the afternoon with a well-rested crew may be far less compelling at 3:00 in the morning on a storm tossed ocean with a fatigued crew.

When I boarded Mr. Foley's boat, I found what appeared to be a law abiding citizen who, after engaging in recreational fishing activity for the better part of the day, had tallied one relatively minor infraction. It would have been quite easy to take option one, tell Mr. Foley to have a nice day and to overlook the offense. Of course, I would have included a little bit of fisheries law education on the side intended to assist Mr. Foley in fully complying with the law on his next fishing trip. For Mr. Foley, with no other boats in sight on his limited three-mile horizon, I suspect this would be the most reasonable course of action. You can almost hear him saying, "Hey, I'm a stand-up guy, let this one fish slide and I'll know better the next time."

What Mr. Foley doesn't realize, but I do as I stand on the bridge of a much more capable vessel, is that there are 
currently thirty other boats in this general area doing the exact same thing as $\mathrm{Mr}$. Foley. I know this because my visible horizon is eight miles, compared to his three, and I have an added radar horizon of twelve to fifteen miles. I also have the experience of the past three days, the patrols over the past month and even the patrols of the past year on which to base an assessment of the severity of the infraction presented by Mr. Foley's eleven-inch fish. My experience has taught me that this type of infraction is common and I know that the overall health of the red snapper fishery in the Gulf of Mexico is in serious decline. The resource is being over-fished to the point that policymakers in Washington, DC are discussing the need to place the fish on the endangered species list. Factors like these caused me to take the stance I did.

While it may appear that I am taking a selective approach in picking and choosing the violations I document, it is worth considering the fact that I am charged with enforcing all applicable federal laws and regulations. Take a moment to consider the depth and breadth of that assignment. It is not possible for me, or even the combined intellect of my crew of sixteen, to begin to enforce every federal statute Congress has passed into law over the past two hundred years. I think it reasonable to assume that I will establish a level of expertise regarding the type of lawful and unlawful activity taking place in my assigned patrol area and establish a patrol focus aimed at mitigating the unlawful activity in the region. The reality of the matter is that I have become an expert on the red snapper fishery while knowing nothing about sea lion rookeries. Conversely, my colleague in Alaska would be hard pressed to cite the laws and regularions relating to the red snapper fishery or the shrimp industry in south Texas.

This localized expertise highlights a dilemma faced by public administrators in agencies across government-the allocation of scarce resources frequently results in the selective enforcement of laws and regulations. The patrol boat that I was in command of was the only Coast Guard resource underway on this day, in this region-some 15,000 square miles of ocean. This solitary resource was, and continues to be, only capable of establishing a law enforcement presence on one vessel at any given time. It is fair to say that the chances of my finding Mr. Foley at this particular time and on this particular day are somewhat like finding a needle in a haystack; I have no doubt that I am finding only a small number of fishery infractions that are taking place in my patrol area at any given time.

Of course, I did not need $\mathrm{Mr}$. Foley to know that. I needed
Mr. Foley to know that he had violated a regulation with significant implications for the future resources of the Gulf of Mexico and the United States. I also wanted Mr. Foley to include in his fishing stories back home that the Coast Guard was choosing to take a narrow interpretation when it came to measuring fish-so make sure your catch is legal. I needed to capitalize on each opportunity to reinforce the deterrent effect associated with my law enforcement presence. Additionally, while it was not possible for my actions to be predictable given the multitude of factors contributing to my ultimate handling of the too-short fish, it was important to me that I approached each case with a similar degree of scrutiny and consideration. I did not want to stop my inquiry at finding the eleven-inch fish. I wanted to know how the fish came to be there, in the cooler, and why. Most importantly, though, I wanted Mr. Foley to be treated with the same degree of reason and equity that I would afford his neighbor tomorrow. In my mind, this was only fair and complied with the concept of social equity.

In reaching a final decision in the case of the eleven-inch fish, I had a number of things to consider. I considered the rule of law provided to me by the elected representative. I considered the efficient, economic, and socially equitable elements of the case at hand. I considered the state of the weather and the competence level of the boarding officer who was conducting the examination aboard "U-Catch-Em." Finally, I considered my mandate, as a public administrator, to act responsibly in the eyes of the policymaker as well as the general public.

I chose to exercise discretion in the case of the eleven-inch fish by seizing the fish and issuing $\mathrm{Mr}$. Foley the notice of violation. In my opinion, the law was clear and it was $\mathrm{Mr}$. Foley's obligation to be familiar with it. Similarly, the longterm viability of the fishery virtually required me to take a hard line stance when it came to measuring the fish and documenting the violation. However, had circumstances been different, had the life of Mr. Foley's crew been in danger or had it been clear that the wind and the waves outmatched his navigation skills, I could have just as easily chosen differently. And I could have done so without thinking too much about the apparent contradiction in the two courses of action.

The public administration community is currently stuck in the vortex of the Friedrich v. Finer debate that I found myself presented with as I considered the eleven-inch fish. Why must we think that the administrator is limited to serving one of two functions, a policy expert under Friedrich or a policy enforcer under Finer? It is time for the discipline 
to accept a third alternative-that the public administrator is the community norm setter and must be afforded latitude in exercising administrative discretion in fostering a civil culture in society.

I view the public administrator as the pseudo-referee in determining where claims on resources achieve equilibrium. For instance, the public interest group would be hard pressed to agree on any circumstance that would justify a fishing vessel anchoring in a sea lion rookery or an eleven-inch red snapper being harvested from the sea. Conversely, left unchecked, fishermen would anchor wherever their individual utility was maximized and take as many fish from the sea as their cargo holds could store. In today's shifting tide of normative behavior, it is the public administrator who then stabilizes societal norms by equitably placing the fulcrum between the competing claims of the public interest group and the fisherman in a way that best serves society-at-large.

In the case of the eleven-inch fish, I chose to narrowly define discretion, but under a slightly different set of circumstances a much broader interpretation of discretion would have been required for me to more effectively serve the public interest. By exercising administrative discretion in this pragmatic fashion, I can be an effective administrator in enforcing the laws of the land while earning the trust and respect of the public at large, my peers, and elected representatives.

\section{Notes}

'H. George Frederickson, The Spirit of Public Administration (San Francisco: Jossey-Bass Publishers, 1997).

${ }^{2}$ Jay M. Shafritz and Albert C. Hyde, comps., Classics of Public Administration (Fort Worth, TX: Harcourt Brace College Publishers, 1978).

'Michael M. Harmon, Responsibility as Parudox: A Critique of Rational Discourse on Government (Thousand Oaks, CA: Sage Publications, 1995).

${ }^{4}$ Frederickson, 98.

${ }^{5}$ Frederickson, 96.

"Carl Friedrich, Bureaucratic Power in National Politics (Boston, MA, Little, Brown, \& Co., 1965).

' It is worch noting that regardless of my ultimate decision in handling this case that the boarding would include an opportunity to educate $\mathrm{Mr}$. Foley on the use of safety and survival equipment as well as federal laws and regulations relating to his boating and fishing activity.

"In this respect, Michael Harmon sums up the Friedrich/Finer debate most succinctly: "Finer represents a hard-core defense of strict accountability, whereas Friedrich, although sharing Finer's overall sentiments concerning the subordination of administration to politics, defends the soft-core alternative, which relaxes strict demands for accountability in the interest of flexibility (Harmon, 1995, 41).

"John P. Burke, Bureaucratic Responsibility (Baltimore, MD, The Johns Hopkins University Press, 1986).

Shafritz \& Hyde, 76.

${ }^{11}$ Michael M. Harmon, Action Theory for Public Administration (New York: Longman, 1981).

"Mark Bovens, The Quest for Responsibility: Citizenship in Complex Organiza" tions (Cambridge, UK, Cambridge University Press, 1998).

"O.C. McSwite, Legitimacy in Rublic Administration: A Discourse Analysis (Thousand Oaks, CA, Sage Publications, 1997),

${ }^{17}$ Garrett Hardin, "The Tragedy of the Commons." Science V162 (December 13, 1968): 1243-1248.

\section{Bibliography}

Bovens, Mark. The Questfor Responsibility: Citizenship in Complex Organications. Cambridge, UK: Cambridge University Press, 1998.

Burke, John P. Bureaucratic Responsibility, Baltimore, MD: The Johns Hopkins University Press, 1986.

Denhart, Kathryn G, The Ethics of Public Service: Resolving Mord Dilemmas in Public Organizations. Westport, CT: Greenwood Press, 1998.

Frederickson, H. George. The Spirit of Public Administration. San Francisco: Jossey-Bass, 1997.

Friedrich, C., H. Finer, \& Francis E. Rourke. Bureaucratic Power in National Politics. Boston, MA: Little, Brown, \& Co, 1965.

Golembiewski, Robert T., and Michael Cohen. Eds. Prople in Itublic Service: A Reader in Public Personnel Administration. Itasca, IL. F.E. Peacock, 1976.

Hardin, Garrett. "The Tragedy of the Commons." Science V162 (December 13, 1968).

Harmon, Michael M. Action Theory for Public Administration. New York: Longman, 1981.

Harmon, Michael M. Responsibility as Panadox: A Critique of Rational Discourse on Crovernment. Thousand Oaks, CA: Sage Publications, 1995.

Kee, James Edwin, and John Shannon, "The Crisis and Anti-crisis Dynamic: Rebalancing the American Federal System." Public Administration Review 52, 4 (1992).

Kidder, Rebeca. Administrative Discretion Gone Awry: "The Reintroduction of the Public Charge Exclusion for HIV-positive Refugees and Asylees." The Yale Law Joumal 106 (Issue 2).

McSwite, O.C. Legitimacy in Public Administration: A Discourse Analysis. Thousand Oaks, CA: Sage Publications, 1997. 
Rohr, John. To Run a Constitution: The Legitimacy of the Administrative State.

Lawrence, KS: University of Kansas Press, 1986.

Shafritz, Jay M., \& Albert C. Hyde, comps, Classics of Public Administration.

$4^{\text {th }}$ ed. Fort Worth, TX: Harcourt Brace, 1978. 
